\title{
THE PERCEPTION OF CORRUPTION IN A CROSS-COUNTRY PERSPECTIVE: WHY ARE SOME INDIVIDUALS MORE PERCEPTIVE THAN OTHERS?
}

\author{
Natalia Melgar * \\ MÁximo Rossi ${ }^{\dagger}$ \\ Tом W. Sмiтн ${ }^{\ddagger}$
}

\begin{abstract}
We examine the foundations of corruption perception at the microlevel. Using micro and macro data, we focus on the incidence of personal characteristics and country effects. We extend previous researches by estimating sub-models taking into account differences in the countries of residence. Our database comes from the 2004 International Social Survey Program survey that includes more than 35 countries. Ordered probit models were estimated in order to study the impact of independent variables on the perceived level of corruption. This article argues that there are socio-demographic variables that play a relevant role in determining corruption perception (such as: gender, education, etc.). We find that country of residence matters and the model shows some relevant patters of behavior. Finally, we find a strong relationship between our ranking of countries and the Corruption Perception Index computed by Transparency International.
\end{abstract}

Keywords: Corruption, Microeconomic behavior, Comparative research JEL classification: D73, K42, O57

\section{Introduction}

The concept of corruption is employed in several areas and its connotations vary widely depending not only on societies but also on people. Corruption is interpreted as a cultural phenomenon. Although there are very different definitions, it is possible to find some elements in common that are connected to the misuse of public office with the purpose of making private gains. This paper focuses on this wide concept of corruption.

Our data source is the module on Citizenship of the 2004 International Social Survey Program (ISSP) survey. This survey asks respondents (approximately 1.000 per country) their opinions on a great variety of issues, including international trade, migration, corruption, politics or religion. In addition, it

\footnotetext{
${ }^{*}$ Universidad de la República. Address: Constituyente 1502, 11200, Montevideo, Uruguay. Email: nmelgar@decon.edu.uy

† Universidad de la República

‡ NORC - University of Chicago
} 
includes demographic and socio-economic data, such as: age, gender, education, etc.

Ordered probit models were estimated in order to study the impact of these multinomial variables on the individual's perception of corruption. We conclude that some socio-demographic variables are significant determinants of the perceived level of corruption (such as: religion, the educational level, the employment sector, among others). Additionally, in almost all cases, the country of residence also has a significant impact. Taking into account economic and political characteristics, we find some clear pattern of behavior. Finally, we show that there is a strong relationship between our ranking of countries and the Corruption Perception Index computed by Transparency International.

The structure of the paper is as follows. The second section is theoretical in nature, and draws on the definition of corruption and the existing and welldeveloped theory on the subject. Section three sketches the main features of the econometric methods applied in this analysis, the data source and the description of variables. The forth section deals with results. Finally, the conclusions are presented in section five.

\section{The Perception of Corruption as a Cultural Phenomenon: Some Insights}

The first problem of any comparative research on corruption is arriving at a definition which lends itself to cross-cultural and cross-national research. However, there is no consensus on what is understood as a corruption. This is mainly driven by the fact that this concept is influenced by cultural and social aspects. For example, Marta et al. (2008) point out that there is a set of background variables and personal characteristics that play a relevant role in shaping ethical perceptions and moral decisions such as religiousness.

In economic terms, there are several ways to define corruption. For example, Werlin (1973) characterizes corruption as the use of public office for private needs and Blackburn et al. (2004, p.5), consider public sector corruption as the illegal, or unauthorized, profiteering by officials who exploit their positions to make personal gains. In order to emphasize the corruption at the public sector, Shleifer \& Vishny (1993, p.2), define it as the sale of state assets by civil servants in order to make gains. Pope (2000) asserts that corruption may take place where there is a combination of opportunity and inclination. Those offering bribes may do so either because they want something they are not entitled to, and bribe the official to bend the rules, or because they believe that the official will not give them their entitlements without some inducements being offered. On the other hand, officials may refuse to serve clients unless a bribe is paid.

This paper focuses on a wide concept of corruption: the misuse of public office with the purpose of making private gains; this definition incorporates the notions of wrongly getting an advantage, pecuniary or otherwise, in violation of official duty and the rights of others.

Hence, if there is non-unique definition of corruption, it seems more difficult for researchers to assess what elements influence on the perception of corruption. In other words, the perceived level of corruption may depend on what the person understands as a corrupt action and also on his/ her personal 
characteristics. Moreover, since the definition of corruption depends on social and cultural factors, the same is true for corruption perception.

Even when corruption perception may differ from the current level of corruption, these phenomena are related and high levels of corruption perception are enough to cause negative effects in the economy. As Lambsdorff (1999) shows corruption perception indexes are good indicators of the real level of corruption and they allow researches to estimate different models with other macroeconomic or socio-demographic data.

In general terms, the perception of corruption has favored the growth of institutional instability and the deterioration of the relationships among individuals, institutions and States. Moreover, the perception of economic corruption would have devastating effects; it generates a "culture of distrust" towards some institutions.

Cábelková (2001) studies the incentives to take corrupt actions and she holds that this problem is affected by the individual perception about the level of corruption and the authority's level of tolerance.

Assuming that the individual is as a rational actor who takes decisions balancing benefits and cost, individual's perception of corruption will vary depending on their individual characteristics such as values and moral views, which modify the perception of the expected costs and expected benefits. While a person could be against bribery regardless of the perceived level of corruption someone else's views could depend on the existing level of corruption.

Hence, following previous researches, (Mocan 2004, Seligson 2002, VanRijckeghem \& Weder 2001, Swamy et al. 2001, Ades \& DiTella 1999, Kaufmann \& Wei 2000, Mocan \& Rees 2005) we hypothesize that personal characteristics are relevant predictors of the perceived level of corruption, given our data set we include variables such as: age, marital status, labor market activity, education, social status, gender and the location of the residence, among others.

Finally, according to Nelken \& Levi (1996) comparative research should not be confined to seeking out what there is in common but also in understanding the many relevant differences that could be connected to different political contexts, culture and economic performance. Therefore, in order to capture these country effects, we added dummies variables representing country of residence.

For example, regarding democracy, it was found that democratic systems tend to reduce corruption perception. Montinola \& Jackman (2002) find that political competition matters because the freedom of information helps monitoring of public officials, thereby limiting their opportunities for corrupt behavior. Moreover, the possible turnover of power implies that politicians cannot always credibly promise that particular laws and regulations will continue. This minimizes the size of bribes that rent-seekers are willing to pay. In line with this, Rose-Ackerman (2001) asserts that a competitive electoral process can give politicians an incentive to reveal the untrustworthy behavior of their opponents and to be trustworthy themselves. As these are proofs of this relationship, we focus on the satisfaction with the democratic system rather than democracy itself. 
Table 1: Distribution of answers

Taking into account your experience, how widespread do you think corruption is in the public service in your country?

\begin{tabular}{lc}
\hline \multicolumn{1}{c}{ Categories } & Frequency $(\%)$ \\
\hline Hardly anyone & 4.28 \\
A small number & 26.86 \\
A moderate number & 30.55 \\
A lot of people & 26.60 \\
Almost everyone & 11.71 \\
\hline Total & 100 \\
\hline
\end{tabular}

\section{Data Source and Methodology}

As mentioned, the data source is the module on Citizenship of the 2004 International Social Survey Program (ISSP) survey. The survey asks respondents their opinions on a great variety of issues, including international trade, migration, politics, taxes and corruption, as well as demographic and socioeconomic information, such as age, gender, education, religiosity and others.

The question used in the survey to identify respondent's perception of corruption is:

Taking into account your experience, how widespread do you think corruption is in the public service in your country?

This question seeks to grasp citizen's perception of corruption and answers take values between 0 and 4 which correspond to the following categories:

- 0 if respondent answers "hardly anyone",

- 1 if respondent indicates "a small number",

- 2 if respondent says "a moderate number",

- 3 if respondent replies "a lot of people" and

- 4 if respondent responds "almost everyone".

Table 1 shows the weighted frequency distribution of the answers to this question in the whole sample (more than 45,000 respondents).

Our ordered probit models aim at determining how different personal characteristics and country of residence shape the formation of opinions towards the level of corruption among civil servants.

The estimated parameters do not provide direct information on the relationship between the independents and dependent variables. Substantive interpretations are based on the prediction of probabilities and functions of these probabilities. These predictions are made for different groups of individuals and the marginal effects of the independent variables are calculated. If the independent variable is binary, the marginal effect is the change from not having a particular characteristic to having it. 
Table 2: Country abbreviations

\begin{tabular}{lllll}
\hline Abbreviation & \multicolumn{1}{c}{ Country } & & Abbreviation & \multicolumn{1}{c}{ Country } \\
\cline { 1 - 1 } \cline { 5 - 6 } AT & Austria & & IL & Israel \\
AU & Australia & & JP & Japan \\
BG & Bulgaria & & KR & South Korea \\
BR & Brazil & & LV & Latvia \\
CA & Canada & & MX & Mexico \\
CH & Switzerland & & NL & Netherlands \\
CL & Chile & & NO & Norway \\
CY & Cyprus & NZ & New Zealand \\
CZ & Czech Republic & PH & Philippines \\
DEE & East Germany & PL & Poland \\
DEW & West Germany & PT & Portugal \\
DK & Denmark & & RU & Russia \\
ES & Spain & & SE & Sweden \\
FI & Finland & SI & Slovenia \\
FLA & Flanders & SK & Slovakia \\
FR & France & TW & Taiwan \\
GB & Great Britain & US & United States \\
HU & Hungary & UY & Uruguay \\
IE & Ireland & VE & Venezuela \\
\hline
\end{tabular}

\section{Results}

The model includes dummy variables representing individual characteristics and in order to capture country effects, we include dummy variables that equal one if respondent lives in that country and zero in other case.

We also compute the marginal effects and their standard errors after estimation. Rather than reporting coefficients, tables 4 and 5 report the discrete change in the probability for each model and significant variable. The marginal effects are nonlinear functions of the estimated parameters, so they cannot generally be inferred directly from the estimated parameters.

As could be seen in table 4 , the probability of perceiving the highest level of corruption, for the whole sample, is $5.6 \%$. MI countries registered the highest probability $(20 \%)$ and the EU shows the lowest probability $(1.9 \%)$.

\subsection{The general model}

As we hypothesized, several personal characteristics play a relevant role in determining the perception of corruption at the micro level.

Firstly, the model shows that there is a significant gender bias and that women are more likely to perceive a higher level of corruption than men.

Secondly, findings indicate that the variables reflecting age are not significant; this result implies that there are no significant differences among age groups or life course adjustment that significantly change the perception of corruption.

Thirdly, we find that marital status matters. While those people who are married tend to perceive a lower level of corruption, the opposite is true for those who are divorced. 
Table 3: Description of independent variables

\begin{tabular}{|c|c|c|}
\hline Variable & Values & Mean \\
\hline \multicolumn{3}{|c|}{ Religion and religiosity } \\
\hline NO_RELIGION & $\begin{array}{l}1 \text { if respondent does not identify } \\
\text { with a religious group }\end{array}$ & 0.20 \\
\hline ATTENDANCE & $\begin{array}{l}1 \text { if respondent attends religious ser- } \\
\text { vices once a week or more }\end{array}$ & 0.19 \\
\hline R_CATHOLIC & $\begin{array}{l}1 \text { if respondents religion is Roman } \\
\text { Catholic }\end{array}$ & 0.37 \\
\hline PROTESTANT & $\begin{array}{l}1 \text { if respondents religion is Protes- } \\
\operatorname{tant}\end{array}$ & 0.22 \\
\hline \multicolumn{3}{|c|}{ Labor market } \\
\hline UNEMPLOYED & 1 if unemployed & 0.08 \\
\hline RETIRED & 1 if retired & 0.19 \\
\hline EMP_FULLTIME & 1 if employed full time & 0.44 \\
\hline PRIVATE_S & 1 if working for a private enterprise & 0.40 \\
\hline SELF_EMPLOYED & 1 if being self-employed & 0.12 \\
\hline UNION & 1 if belonging to an union & 2.33 \\
\hline \multicolumn{3}{|c|}{ Human Capital } \\
\hline EDU_LEVEL2 & $\begin{array}{l}1 \text { if respondent is above lowest qual- } \\
\text { ification }\end{array}$ & 0.20 \\
\hline EDU_LEVEL3 & $\begin{array}{l}1 \text { if respondent has completed higher } \\
\text { secondary or above higher secondary } \\
\text { level }\end{array}$ & 0.38 \\
\hline EDU_LEVEL4 & $\begin{array}{l}1 \text { if respondent has a university de- } \\
\text { gree }\end{array}$ & 0.15 \\
\hline \multicolumn{3}{|c|}{ Place of residence } \\
\hline URBAN & $\begin{array}{l}1 \text { if respondent lives in a big city, sub- } \\
\text { urb or outskirt of a big city }\end{array}$ & 0.44 \\
\hline \multicolumn{3}{|c|}{ Other socio-demographic variables } \\
\hline WOMAN & 1 being a woman & 0.53 \\
\hline AGE18-39 & $\begin{array}{l}1 \text { if respondent's age is between } 18 \\
\text { and } 39 \text { years old }\end{array}$ & 0.40 \\
\hline AGE40-60 & $\begin{array}{l}1 \text { if respondent's age is between } 40 \\
\text { and } 60 \text { years old }\end{array}$ & 0.38 \\
\hline MARRIED & 1 if married or living as married & 0.57 \\
\hline DIVORCED & 1 if divorced & 0.08 \\
\hline \multicolumn{3}{|c|}{ Others variables } \\
\hline DEM_TODAY & $\begin{array}{l}1 \text { if respondent places the state of } \\
\text { democracy in his country among } 5 \text { to } \\
10\end{array}$ & 0.72 \\
\hline
\end{tabular}




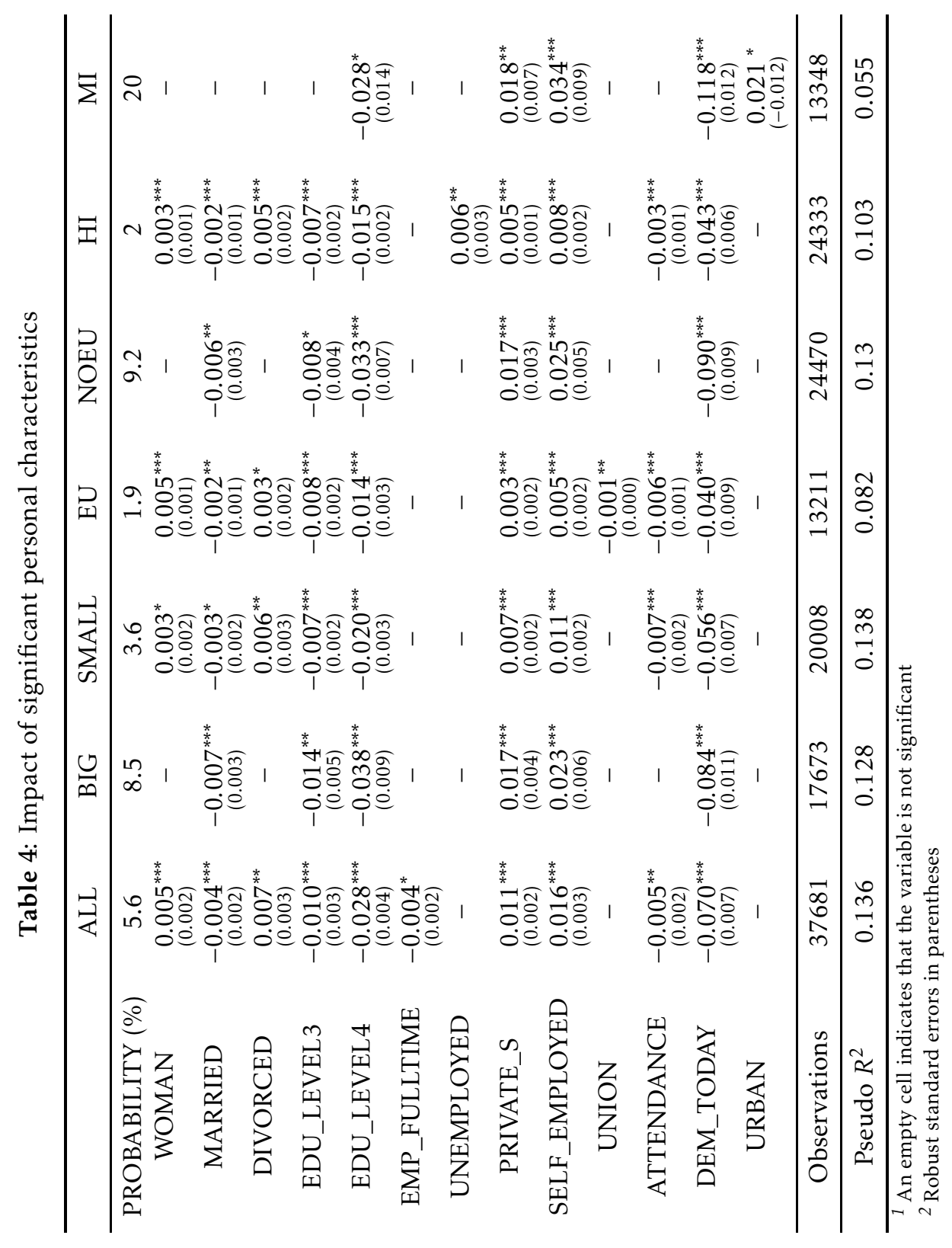



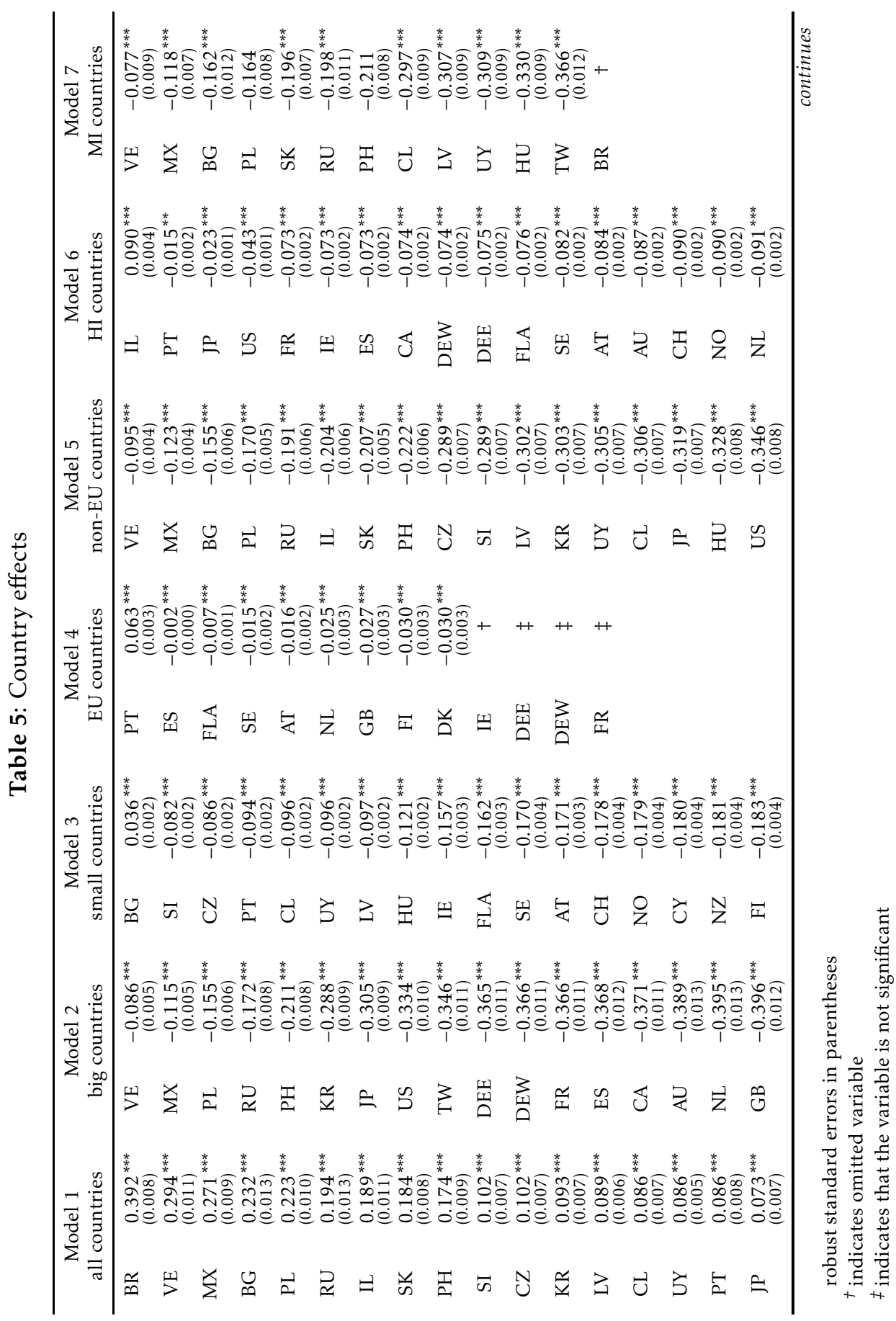


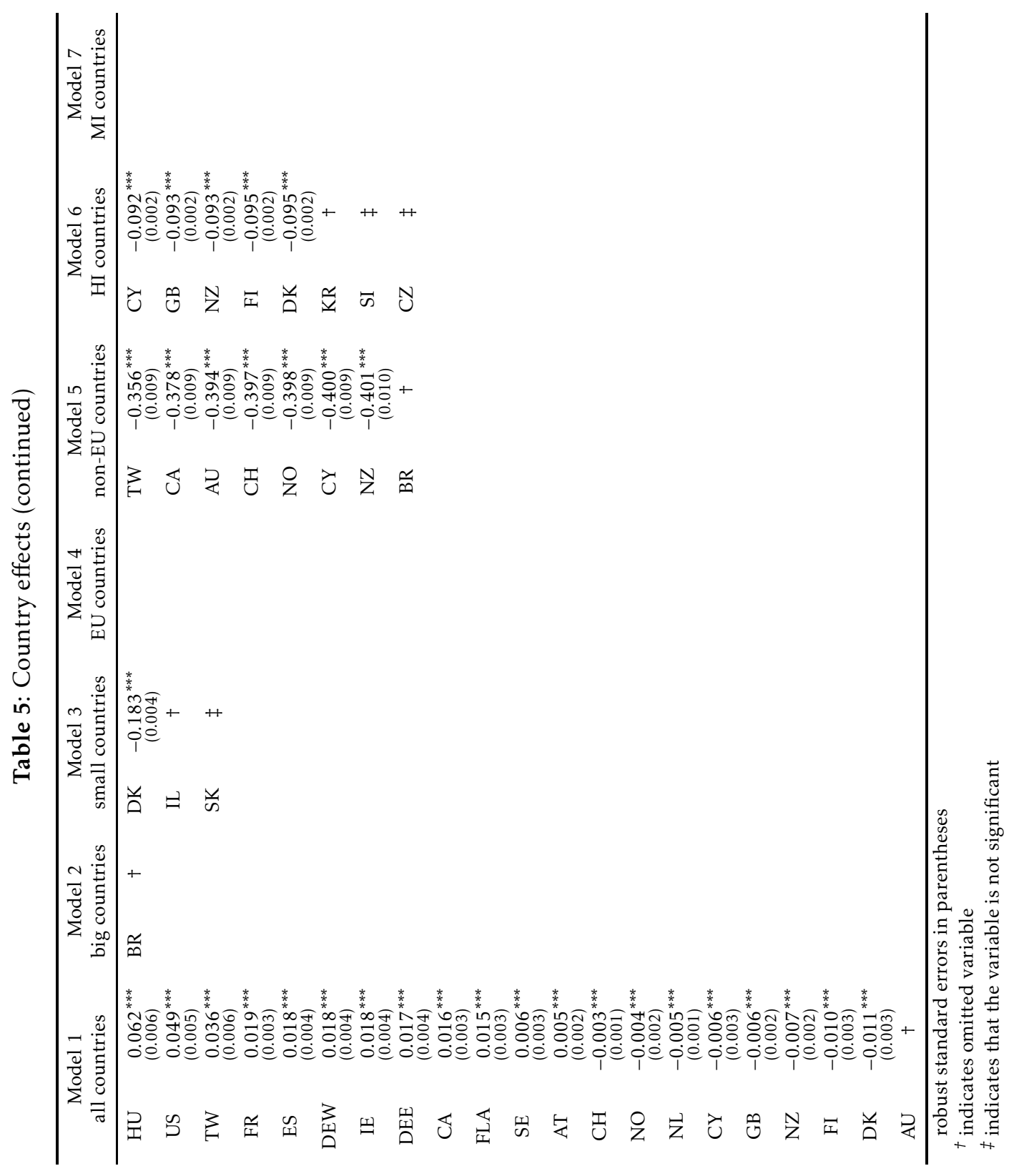


Moreover, as it was expected, the educational level is a relevant determinant of the perceived level of corruption. It is found that people who have completed, at least, secondary are more prone to perceive a lower level of corruption. This result could imply that the access to the information and the capability to process this information matter. More educated people have more information and better capabilities to process it. This fact shapes the perception of corruption at the micro level.

Regarding religion and religiosity, the models also confirms our hypothesis. Firstly, there are no significant differences among religious groups (Roman Catholic, Protestant and others) and the same happens if we compare people who identifies with some religious group and atheists. On the other hand, the degree of religiosity does influence corruption perception; the probability of perceiving the highest level of corruption declines 0.5 percentage points if the person attends to religious services frequently.

Concerning labor market, we provide evidence on the significant impact of being self-employed. Specifically, this group of people tends to perceive a higher level of corruption. It might be possible that they are exposed to more incidents of corruption. The opposite is true in the case of full-time workers; these people tend to perceive a lower level of corruption.

Additionally, the sector of employment is a relevant determinant of corruption perception. Those who are working in a private enterprise are more likely to perceive a higher level of corruption than those who are employed in the public sector. It is worth noting that those people who are on the demand side of the "bribes market" tend to perceive lower level of corruption than those people who are on the supply side of this market. The model also shows that other characteristics such as being unemployed, being retired and belonging to a union make no relevant differences.

Connected to democracy, we find that those who have a favorable opinion on democracy are more likely to perceive a lower level of corruption. Hence, favorable opinions towards the political systems positively contribute to the opinions about the level of corruption. In line with this finding, Goldsmith (1999) and Sandholtz \& Koetzle (2000) argue that people living in countries with democratic systems tend to perceive lower levels of corruption and citetTreisman 2000 shows that the same is true in the case of long exposure to democracy.

Taking into account the place of residence, results indicate that on one hand, there is no significant difference among people living in urban areas and others but on the other hand, it is worth noting that all country dummies are significant. This result means that there are significant cultural and political differences that influence the perception of corruption. While most of them show a positive sign, there is a small group of countries that register a negative sign. We will explain this difference later.

Given the mentioned results we estimated six additional models by considering different groups of countries. We take into account the following criteria: 1) population, we classified countries as big (if inhabitants were 14,345, the sample mean, or higher) and small (in other case), 2) European Union (EU) countries, (as the survey was carried out during 2004, we consider the group of countries that were members in 2003) and others countries and 3) income level: middle income (MI) countries and high income (HI) countries (World Bank classification, Atlas Method). 


\subsection{The sub-models}

We find that there is a set of results that are maintained in all sub-models, in other words, they do not depend on the specific country's characteristics.

In all sub-sample models, results indicate that: 1) the variables reflecting individual's age are not significant, 2) the education level has a relevant and negative role in determining corruption perception, 3) there are no significant differences among religious groups, 4) self-employed people tend to perceive a higher level of corruption and as before the sector of employment is a determinant of corruption perception and 5) those who have a favorable opinion on democracy are more likely to perceive a lower level of corruption.

Additionally, the sub-models also show various relevant specificities.

Firstly, the gender bias remains significant in three models (small countries, EU countries and HI countries) and as before, that women are more likely to perceive a higher level of corruption than men.

Secondly, even when five sub-models show that married people tend to perceive a lower level of corruption, this is not true in the case of those living in MI countries. Moreover, those who are divorced are likely to perceive a higher level of corruption in small countries, EU countries and HI countries.

Thirdly, religiosity seems to play a relevant role only in the following cases: small countries, EU countries and HI countries and as before, it decreases the probability of perceiving the higher level of corruption.

Moreover, it is worth noting that only in HI countries, there is a significant difference among people who are unemployed and those who are employed. Moreover, only in the case of EU countries, those people who belong to a union are more likely to perceive a lower level of corruption.

When considering the place of residence, findings indicate that only in one case, MI countries, there is a significant difference between those who live in urban areas who are less likely to perceive a higher level of corruption than people living in rural areas.

Finally, it is worth noting that when examining country dummies, almost all variables are significant. This result might mean that significant cultural and political differences that influence the perception of corruption remain even when the countries have some characteristic in common.

\subsection{Country effects}

Firstly, we examine model 1 that includes all countries. However, sub-samples models show that country effects remain significant. This finding indicate that even when we consider groups of countries that have some characteristic in common, there are cultural, economic, political etc. influences that makes significant differences in the perceived level of corruption.

\section{The general model}

The biggest impacts are found in Latin American countries: Brazil, Venezuela and Mexico. In these cases, the probability raises 39.2, 29.4 and 27.1 percentage points respectively. In other words, Brazilians, Venezuelans and Mexicans tend to perceive a higher level of corruption.

Moreover, all Latin American countries are ranked in the first half of the table; the change is higher than the average. In this group of countries, Chile and Uruguay registered the smallest identical impact ( 8.6 percentage points). 
Something similar happens in the case of Asia, with the exemption of Taiwan, all countries are found in the first half of the table. On the contrary, with the exemption of Portugal, EU countries rank in the second half of the table. Similarly, Canada and United States, which belong to America but with very different economic performance and cultural characteristics than Latin American countries, show lower values (1.6 and 4.9 percentage points, respectively). Additionally, all Anglo-settlement colonies (Canada, New Zealand and United States) fall in the bottom half as do the majority of rich countries.

As mentioned, our sample included 37 countries and only in eight cases, we find a negative impact on the probability: Switzerland $(-0.3$ percentage points), Norway ( -0.4 percentage points), Cyprus ( -0.6 percentage points), Netherlands ( -0.5 percentage points), Great Britain ( -0.6 percentage points), New Zealand $(-0.7$ percentage points), Finland ( -1 percentage points) and Denmark $(-1.1$ percentage points). It is worth noting that all of these countries are rich, small and four of them belong to the EU.

These results are in line with Sandholtz \& Koetzle (2000) and Treisman (2000) who show that higher economic development is a good predictor of lower perceived corruption. Moreover, Mauro (1995) argue that higher perception of corruption is associated with a slower rate of economic growth.

Analyzing political characteristics, we find another clear pattern of behavior. The former Socialist states of Eastern Europe are located in the first half of the table showing impacts to 23.2 percentage points from 6.2 percentage points, countries ranked as follow: Bulgaria, Poland, Russia, Slovakia, Slovenia, Czech Republic, Latvia and Hungary. This result could be related to the past experiences of corruption at the governmental level than to present events.

Regarding others characteristics such as whether the country was a colony or official language, we do not find a clear pattern of behavior.

Given our previous results, we examine whether there is a relationship among our ranking of countries and the Corruption Perception Index (CPI, 2004) computed by Transparency International. As could be seen in table 6 , the rankings seem to be related. In order to prove this, we employed the Spearman's rank correlation test. The null hypothesis established that the variables are independent.

As expected we find that these rankings are correlated; the correlation coefficient is 88.13 and the null hypothesis was rejected at $1 \%$.

\section{The sub-models}

Firstly, it should be noted that almost all country dummies remain significant and the ranking of countries also remains. Hence, even when all countries in a sub-sample have some element in common, the significant differences among them remain. The marginal effects and the positions should be reinterpreted by considering that the omitted variable has changed.

Secondly, the sub-models add some elements to the discussion. When considering big countries (model 2), we find that Anglo-settlement colonies show a different pattern of behavior: while United States is found in the first half of the table, Canada and Australia registered larger changes that imply much greater differences with Brazil (the omitted variable). Small countries model (model 3) shows lower heterogeneity than the previous model and the biggest 
Table 6: Corruption Perception Rankings

\begin{tabular}{|c|c|c|}
\hline Country & $\begin{array}{c}\text { Our ranking } \\
\text { (percentage } \\
\text { points) }\end{array}$ & $\begin{array}{c}\text { Transparency } \\
\text { International, } \\
\text { CPI } 2004\end{array}$ \\
\hline Brazil & 39.2 & 3.9 \\
\hline Venezuela & 29.4 & 2.3 \\
\hline Mexico & 27.1 & 3.6 \\
\hline Bulgaria & 23.2 & 4.1 \\
\hline Poland & 22.3 & 3.5 \\
\hline Russia & 19.4 & 2.8 \\
\hline Israel & 18.9 & 6.4 \\
\hline Slovak & 18.4 & 4.0 \\
\hline Philippines & 17.4 & 2.6 \\
\hline Slovenia & 10.2 & 6.0 \\
\hline Czech Republic & 10.2 & 4.2 \\
\hline South Korea & 9.3 & 4.5 \\
\hline Latvia & 8.9 & 4.0 \\
\hline Chile & 8.6 & 7.4 \\
\hline Uruguay & 8.6 & 6.2 \\
\hline Portugal & 8.6 & 6.3 \\
\hline Japan & 7.3 & 6.9 \\
\hline Hungary & 6.2 & 4.8 \\
\hline United States & 4.9 & 7.5 \\
\hline Taiwan & 3.6 & 5.6 \\
\hline France & 1.9 & 7.1 \\
\hline Spain & 1.8 & 7.1 \\
\hline Ireland & 1.8 & 7.5 \\
\hline Germany & 1.8 & 8.2 \\
\hline Canada & 1.6 & 8.5 \\
\hline Sweden & 0.6 & 9.2 \\
\hline Austria & 0.5 & 8.4 \\
\hline Australia & 0.0 & 8.8 \\
\hline Switzerland & -0.3 & 9.1 \\
\hline Norway & -0.4 & 8.9 \\
\hline Netherlands & -0.5 & 8.7 \\
\hline Cyprus & -0.6 & 5.4 \\
\hline Great Britain & -0.6 & 8.6 \\
\hline New Zealand & -0.7 & 9.6 \\
\hline Finland & -1.0 & 9.7 \\
\hline Denmark & -1.1 & 9.5 \\
\hline
\end{tabular}

negative impacts are found in European countries (such as Denmark and Finland.

In the case of EU countries (model 4), the omitted variable is Ireland and the model shows that in almost all cases country variables register a negative sign; indicating that inhabitants of these countries tend to perceive a lower level of corruption that Irelands. Portugal is the sole exemption what means that among EU citizens, Portuguese are likely to perceive the highest level of corruption. On the other extreme, Danish und Finnish tend to perceive the lowest level of corruption. Regarding non-EU countries (model 5), once again Venezuela and Mexico are found at the top of the table, followed by Asian and other Latin American countries. All Anglo-settlement colonies and all European rich countries fall in the bottom half. Taking into account political characteristics, we find once again, that the former Socialist states of Eastern Europe are located in the first half of the table. 
Considering HI countries (model 6), findings indicate that with the exemption of Israel, all people perceive a lower level of corruption that those living in South Korea. It is important to notice that Czech Republic and Slovenia (ex-Socialist states of Eastern Europe) are not significant and that, there is no Latin American country in this sub-sample. Regarding EU countries, Portugal shows the smaller negative impact. Once again, Anglo-settlement colonies present a heterogeneous behavior: while Canada and United States rank in the first half of the table, New Zealand is situated in the second half. Regarding MI countries (model 7) all country variables show a significant negative impact in the assessed probability with respect to Brazil. While Venezuela and Mexico ranked first, Uruguay and Chile are found in the second half of the table. This sub-sample includes European countries and all of them are former Socialist states of Eastern Europe. While Bulgaria, Poland, Slovakia and Russia are situated in the first half of the table; Latvia and Hungary are founded in the second half.

\section{Conclusions}

This study's main contributions are threefold and we extend previous literature and previous public opinion research examining not only personal characteristics but also country effects.

Firstly, by employing a large dataset and estimating by country groups, we present econometric evidence that verify previous findings. Being a woman, the education level, the marital status, the attendance to religious services, being self-employed and the opinions towards the political system, among others, are factors that modify the probability of perceiving corruption.

Secondly, new evidence was provided about the effects of the sector of employment. In all models, those who work in the private sector are more likely to perceive higher corruption than civil servants. This means that those people who are on the demand side of the "bribes market" tend to perceive lower corruption than those people who are on the supply side of this market.

Thirdly, taking into account country-effects, as expected; in almost all cases country dummies are significant. Findings indicate that country effects are linked to past experiences of corruption or the lack of them as well as to economic development, well-being and cultural factors. We find that all Latin American countries show changes which are higher than the average and the same is true for ex-Socialist states and the majority of East Asian countries. On the contrary, with the exemption of Portugal, European countries showed lower changes than the average. We also find that all Anglosettlement colonies fall in the bottom half as do the majority of rich countries.

Finally, we find that our ranking of countries is correlated with Transparency International Corruption Perception Index (2004); the correlation coefficient is -88.13 .

\section{Bibliography}

Ades, A. \& DiTella, R. (1999), 'Rents, competition and corruption', American Economic Review 89, 982-993.

Blackburn, K., Bose, N. \& Haque, M. (2004), Endogenous corruption in economic development, Technical report, University of Nottingham. 
Cábelková, I. (2001), Perceptions of corruption in ukraine: Are they correct?, Technical report, CERGE-EI.

Goldsmith, A. (1999), 'Slapping the grasping hand: correlates of political corruption in emerging markets', American Journal of Economics and Sociology $53,865-883$.

Kaufmann, D. \& Wei, S. J. (2000), Does "grease money" speed up the wheels of commerce?, Technical report, International Monetary Fund.

Lambsdorff, J. G. (1999), The Transparency International Corruption Perceptions Index, Transparency International Newsletter.

Marta, J., Heiss, C. \& DeLugio, S. (2008), 'An explanatory comparison of ethical perceptions of Mexican and U.S. marketers', Journal of Business Ethics 82, 539-555.

Mauro, P. (1995), 'Corruption and growth', Quarterly Journal of Economics 110, 681-712.

Mocan, N. (2004), 'What determines corruption? international evidence from micro-data', Economic Inquiry 46, 493-510.

Mocan, N. \& Rees, D. (2005), 'Economic conditions, deterrence and juvenile crime: evidence from micro data', American Law and Economics Review 7, 319-349.

Montinola, G. \& Jackman, R. W. (2002), 'Sources of corruption: a crosscountry study', British Journal of Political Science 32, 147-170.

Nelken, D. \& Levi, M. (1996), 'The corruption of politics and the politics of corruption: an overview', Journal of Law and Society 23, 1-17.

Pope, J. (2000), Transparency International, Confronting Corruption: The Elements of a National Integrity System, Transparency International Source Book.

Rose-Ackerman, S. (2001), 'Trust, honesty and corruption: reflection on the state-building process', European Journal of Sociology 42, 27-71.

Sandholtz, W. \& Koetzle, K. (2000), 'Accounting for corruption: economic structure, democracy and trade', International Studies Quarterly 44, 31-50.

Seligson, M. (2002), 'The impact of corruption on regime legitimacy: a comparative study of four latin american countries', The Journal of Politics 64, 408-433.

Shleifer, A. \& Vishny, R. (1993), 'Corruption', Quarterly Journal of Economics 108, 599-617.

Swamy, A., Knack, S., Lee, Y. \& Azfar, O. (2001), 'Gender and corruption', Journal of Development Economics 64, 25-55.

Treisman, D. (2000), 'The causes of corruption: a cross-national study', Journal of Public Economics 76, 399-457. 
VanRijckeghem, C. \& Weder, B. (2001), 'Bureaucratic corruption and the rate of temptation: do wages in the civil service affect corruption and by how much?', Journal of Development Economics 65, 307-331.

Werlin, H. (1973), 'The consequences of corruption: The ghanaian experience', Political Science Quarterly 88, 71-85. 